\title{
Jumlah Coliform, BAL dan Total Bakteri Usus Halus Ayam Broiler yang Diberi Kunyit (Curcuma domestica)
}

\section{Total Coliform, Acid Bacteria and Total Bacteria in Intestine of Broiler Chicken Given Turmeric}

\author{
R. Halimatunnisroh", T. Yudiarti dan Sugiharto \\ Fakultas Peternakan dan Pertanian, Universitas Diponegoro, Semarang, 50275 \\ ${ }^{*}$ E-mail: halimatunnisrohrisa@gmail.com \\ (Diterima: 20 Maret 2017; Disetujui: 4 Mei 2017)
}

\begin{abstract}
ABSTRAK
Penelitian ini bertujuan untuk mengetahui pengaruh pemberian air rebusan kunyit terhadap total bakteri coliform, bakteri asam laktat (BAL) dan total bakteri dalam usus halus ayam broiler. Materi yang digunakan yaitu 200 ekor ayam broiler DOC (Day Old Chick), strain Lohman, bobot badan rata-rata 41,48 $\pm 0,99 \mathrm{~g}$. Ternak dipelihara selama 35 hari dan perlakuan pemberian air rebusan kunyit pada air minum mulai diberikan pada umur 11 hari. Rancangan penelitian yang digunakan yaitu Rancangan Acak Lengkap (RAL) dengan 5 perlakuan dan 5 ulangan, setiap ulangan terdiri dari 8 ekor. Perlakuan yang digunakan yaitu T0 (100\% air), T1 (25\% air rebusan kunyit : 75\% air), T2 (50\% air rebusan kunyit : 50\% air), T3 (75\% air rebusan kunyit : 25\% air), dan T4 (100\% air rebusan kunyit). Parameter yang diamati yaitu jumlah coliform, BAL, dan total bakteri dalam usus halus. Hasil penelitian menunjukkan bahwa pemberian air rebusan kunyit pada air minum ayam broiler berpengaruh nyata $(\mathrm{p}<0,05)$ terhadap jumlah $\mathrm{BAL}$ dan total bakteri, tetapi tidak berpengaruh $(\mathrm{p}>0,05)$ terhadap jumlah coliform. Keimpulannya, bahwa pemberian air rebusan kunyit tidak meningkatkan/menurunkan total bakteri coliform tetapi menurunkan total bakteri dan meningkatkan total BAL.
\end{abstract}

Kata kunci: kunyit, ayam broiler, bakteri

\section{ABSTRACT}

The aim of this study was to investigate the effect of boiled turmeric water on total coliform bacteria, lactic acid bacteria (BAL) and total bacteria in the small intestine of broiler chicken. 200 day-old-chick (DOC) Lohman strain with the average initial body weight of 41,48 0,99 $\mathrm{g}$ were used. Chickens kept for 35 days and the treatment of turmeric water in drinking water start given at 11 days old. The experimental design was Completely Randomized Design (RAL) were used with 5 treatments and 5 replications, which each replication consist of 8 chicken. The treatments were T0 (100\% water), T1 (25\% boiled turmeric water : 75\% water), T3 (75\% boiled turmeric water : 25\% water), and T4 (100\% boiled turmeric water). Parameters that investigated were total coliform, BAL, and total bacteria in the small intestine. The results of boiled turmeric water in drinking water of broiler chicken small intestine that shows significant different $(p<0.05)$ on total BAL and total bacteria but showing no different $(p>0.05)$ on total coliform. Conclusion, that boiled turmeric water in drinking water not increasing/decreasing total coliform but decreasing total bacteria and increasing $B A L$.

Keywords: tumeric, broiler, bacteria

\section{PENDAHULUAN}

Ayam broiler merupakan salah satu komoditas peternakan yang banyak diminati oleh konsumen karena memiliki kandungan nutrisi yang tinggi dengan harga yang lebih murah dibandingkan dengan ternak lain. Ayam broiler memiliki sifat unggul yaitu tidak membutuhkan tempat luas dalam pemeliharaan, pertumbuhan cepat dan memiliki efisiensi pakan yang baik (Estancia et al., 2012). Pertumbuhan dan produksi ayam 
broiler dapat dipengaruhi oleh beberapa faktor diantaranya yaitu kesehatan ayam broiler.

Saluran pencernaan merupakan organ yang memiliki fungsi sebagai pencerna pakan serta fungsi imunologis (sebagian besar sel-sel imun diproduksi di usus). Terkait dengan fungsi pencerna pakan, penyerapan nutrisi pakan dapat berlangsung optimal apabila kondisi usus dalam keadaan sehat dan baik. Kesehatan usus salah satunya dipengaruhi oleh populasi mikroba yang ada didalamnya diantaranya yaitu bakteri. Bakteri menguntungkan yang ada di usus halus misalnya bakteri asam laktat (BAL) sedangkan bakteri patogen misalnya bakteri coliform.

Jumlah bakteri coliform dalam usus halus dapat diminimalisir dengan penambahan antibiotik yang merupakan suatu zat yang dapat mengontrol pertumbuhan bakteri patogen. Akan tetapi, antibiotik yang digunakan dalam waktu yang panjang dapat menimbulkan residu antibiotik pada daging ayam broiler sehingga berbahaya bagi konsumen dan menimbulkan resisten antibiotik (Anggitasari et al., 2016). Karena adanya dampak negatif yang timbul akibat penggunaan antibiotik, maka perlu pengganti salah satunya yaitu kunyit.

Kunyit (Curcuma domestica) dapat digunakan sebagai antibiotik alami karena mengandung kurkumin yang mampu menekan pertumbuhan mikroba patogen (Natsir et al., 2016). Kurkumin dapat mendenaturasi dan merusak membran sel bakteri patogen sehingga proses metabolismenya terganggu, pertumbuhan bakteri berkurang dan aktivitasnya menjadi terhambat. Penurunan jumlah bakteri patogen akan meningkatkan jumlah bakteri non patogen diantaranya yaitu bakteri asam laktat (BAL). Penambahan kunyit pada level $0,2 \%$ pada pakan mampu meningkatkan total bakteri asam laktat pada usus halus ayam broiler dari 13,99 $\mathrm{log} \mathrm{cfu} / \mathrm{ml}$ menjadi 17,09 log cfu/ml. Berdasarkan latar belakang diatas, maka dilakukan penelitian untuk melihat jumlah bakteri coliform, bakteri asam laktat, dan total bakteri dalam usus halus dari ayam broiler yang diberi air rebusan kunyit.

Penelitian ini bertujuan untuk mengetahui jumlah bakteri coliform, bakteri asam laktat, dan total bakteri dalam usus halus dari ayam broiler yang diberi air rebusan kunyit. Manfaat dari penelitian ini adalah memberikan informasi mengenai potensi air rebusan kunyit sebagai alternatif pengganti antibiotik sintetik ayam broiler.

\section{METODE}

\section{Tempat Penelitian}

Penelitian ini dilaksanakan pada bulan Oktober-Desember 2016 di Kandang Unggas, Laboratorium Produksi Ternak Unggas dan di Laboratorium Fisiologi dan Biokimia, Fakultas Peternakan dan Pertanian, Universitas Diponegoro, Semarang.

\section{Materi Penelitian}

Penelitian menggunakan materi berupa 200 ekor ayam broiler DOC (Day Old Chick), strain Lohman jenis kelamin jantan dan betina, bobot badan rata-rata 41,48 $\pm 0,99 \mathrm{~g}$. Jumlah kandang yang digunakan berjumlah

Tabel 1. Kandungan Nutrisi Pakan.

\begin{tabular}{lcc}
\hline Kandungan Nutrien & B-11S (Starter) & BR-IAJ (Finisher) \\
\hline Kadar Air (Max.) (\%) & 13,00 & 13,00 \\
Protein (\%) & $21,00-23,00$ & $20,50-22,50$ \\
Lemak (Min.) (\%) & 5,00 & 5,00 \\
Serat Kasar (Max.) (\%) & 5,00 & 5,00 \\
Abu (Max.) (\%) & 7,00 & 7,00 \\
Kalsium (Min.) (\%) & 0,90 & 0,90 \\
Fosfor (Min.) (\%) & 0,60 & 0,60 \\
\hline
\end{tabular}


25 petak dengan alas berupa sekam, pemeliharaan ayam dilakukan sampai umur 35 hari. Bahan pakan berupa pakan komersil yang berasal dari pabrik (Tabel 1.) dan bahan baku air minum berupa air dan kunyit. Kunyit diperoleh dari daerah Tembalang, Semarang. Alat yang digunakan dalam kandang berupa tempat pakan dan minum, timbangan analitik, kompordan termohygrometer.

Alat yang digunakan untuk analisis bakteri yaitu oven, autoklaf, erlenmeyer, pipet, tabung reaksi, cawan petri, inkubator, dan hand counter. Medium yang digunakan untuk menumbuhkan bakteri yaitu PDA (Potato Dextrose Agar), Mac Conkey Agar, dan MRSA (deMann Rogosa Sharpe Agar).

\section{Pelaksanaan Penelitian}

Penelitian menggunakan rancangan acak lengkap (RAL) dengan 5 perlakuan dan 5 ulangan, tiap unit percobaan terdiri dari 8 ekor ayam broiler. Perlakuan pemberian air rebusan kunyit dilakukan pada saat ayam berumur 11 hari hingga berumur 35 hari. Perlakuan yang diberikan adalah T0 $=100 \%$ air biasa, $\mathrm{T} 1=25 \%$ air rebusan kunyit $+50 \%$ air biasa, $\mathrm{T} 2=50 \%$ air rebusan kunyit $+50 \%$ air biasa , $\mathrm{T} 3=75 \%$ air rebusan kunyit $+25 \%$ air biasa, $\mathrm{T} 4=100 \%$ air rebusan kunyit.

Air rebusan kunyit diperoleh dengan cara 167 gram kunyit segar digeprek hingga halus, kemudian direbus selama 10 menit dalam 10 liter air biasa yang telah mendidih selanjutnya didinginkan. Pembuatan air minum dengan cara mencampur air rebusan kunyit dengan air biasa sesuai dengan presentase perlakuan.

Komposisi dan kandungan nutrisi pakan dapat dilihat pada Tabel 1. Tahap pelaksanaan penelitian dengan pemberian pakan dan air minum setiap hari secara adlibitum.Parameter yang diamati yaitu jumlah bakteri coliform, bakteri asam laktat, dan total bakteri pada usus halus. Perhitungan total bakteri menggunakan metode TPC (Total Plate Count).

Pengambilan sampel dilakukan ketika ayam berumur 35 hari. Ayam diambil 1 ekor secara acak dari masing-masing flok kemudian ayam disembelih dan diambil bagian usus halusnya. Cairan digesta yang ada di dalam usus halus diambil kemudian diletakkan di dalam plastik klip selanjutnya dibawa ke laboratorium untuk dilakukan pengujian. Sterilisasi alat, medium, dan tabung reaksi yang berisi aquades $9 \mathrm{ml}$. Sterilisasi alat dengan menggunakan oven suhu $170^{\circ} \mathrm{C}$ selama 1 jam sedangkan sterilisasi medium dan tabung reaksi menggunakan autoklaf selama 15 menit.

Pengenceran sampel yaitu dengan cara 1 gr cairan digesta dimasukkan kedalam tabung reaksi pertama yang berisi $9 \mathrm{ml}$ aquades kemudian dilakukan homogenisasi dan diperoleh pengenceran $10^{-1} .1 \mathrm{ml}$ dari tabung pertama kemudian dimasukkan ke tabung kedua, tabung tersebut dikocok hingga homogen dan diperoleh pengenceran $10^{-2}, 1$ $\mathrm{ml}$ dari tabung kedua kemudian dimasukkan ke tabung ketiga, tabung tersebut dikocok dan diperoleh pengenceran $10^{-3}$, dilakukan pengenceran sampai $10^{-10}$. Medium yang telah disterilisasi kemudian dituangkan kedalam cawan petri dan ditunggu sampai padat. Uji coliform menggunakan pengenceran $10^{-3}$ dan $10^{-4}$ sebanyak $1 \mathrm{ml}$ dan diteteskan pada cawan petri yang berbeda. Uji bakteri asam laktat menggunakan pengenceran $10^{-5}$ dan $10^{-6}$, cawan petri ditambah anaerocult dan dibungkus plastik untuk membuat suasana anaerob. Uji total bakteri menggunakan pengenceran $10^{-9}$ dan $10^{-10}$. Cawan berisi sampel diinkubasi pada suhu $37^{\circ} \mathrm{C}$ selama 24 jam untuk uji bakteri coliform serta total bakteri dan suhu $37^{\circ} \mathrm{C}$ selama 48 jam untuk uji bakteri asam laktat. Setelah diinkubasi koloni dihitung berdasarkan jenis bakteri yang terlihat selanjutnya perhitungan jumlah bakteri yang sesungguhnya menggunakan rumus excel.

\section{HASIL DAN PEMBAHASAN}

Total bakteri, bakteri coliform, dan Bakteri Asam Laktat (BAL) pada usus halus ayam broiler akibat pemberian air rebusan kunyit disajikan dalam Tabel 2. 
Tabel 2. Total bakteri, bakteri coliform, dan bakteri asam laktat pada usus halus ayam broiler pada berbagai dosis penambahan air rebusan kunyit dalam air minum.

\begin{tabular}{lccc}
\hline Perlakuan & Total Bakteri & Coliform $(c f u / g)$ & BAL $(c f u / g)$ \\
\hline T0 & $4,20 \times 10^{12 \mathrm{a}}$ & $1,70 \times 10^{6}$ & $1,30 \times 10^{8 \mathrm{ab}}$ \\
T1 & $2,20 \times 10^{12 \mathrm{ab}}$ & $0,70 \times 10^{6}$ & $4,20 \times 10^{8 \mathrm{a}}$ \\
T2 & $0,80 \times 10^{12 \mathrm{bc}}$ & $1,60 \times 10^{6}$ & $1,10 \times 10^{8 \mathrm{~b}}$ \\
T3 & $1,10 \times 10^{12 \mathrm{bc}}$ & $1,30 \times 10^{6}$ & $2,50 \times 10^{8 \mathrm{ab}}$ \\
T4 & $0,40 \times 10^{12 \mathrm{c}}$ & $1,00 \times 10^{6}$ & $4,10 \times 10^{8 \mathrm{a}}$ \\
\hline
\end{tabular}

Keterangan: Superskrip yang berbeda pada kolom yang sama menunjukkan perbedaan nyata $(\mathrm{P}<0,05)$

\section{Total Bakteri pada Usus Halus Ayam Broiler}

Hasil analisis ragam menunjukkan bahwa terdapat pengaruh perlakuan pemberian air rebusan kunyit pada air minum terhadap total bakteri dalam usus halus ayam broiler $(\mathrm{P}<0,05)$. Total bakteri menunjukkan jumlah semua bakteri yang ada didalam usus halus ayam broiler baik bakteri patogen maupun bakteri non patogen. Pemberian air rebusan kunyit pada penelitian ini dapat menurunkan total bakteri pada usus halus ayam broiler (T0 vs T1, T2, T3 dan T4). Hal ini sesuai dengan pendapat Namagirilakshmi et al. (2010) bahwa penambahan kunyit dengan level $1 \%$ pada pakan mampu menurunkan total bakteri pada usus halus ayam broiler sebanyak 48\% dibandingkan dengan kontrol. Penurunan total bakteri disebabkan karena kunyit mengandung senyawa kurkuminyang bersifat antimikroba, yaitu senyawa yang dapat menurunkan jumlahmikroba patogen termasuk didalamnya yaitu bakteri patogen. Sebagaimana pendapat Natsir et al. (2016) menyatakan bahwa kunyit dapat digunakan sebagai pengganti antibiotik sintetik karena mengandung senyawa aktif kurkumin yang mampu menekan mikroba patogenpada ayam broiler.

Bakteri yang menurun dimungkinkan adalah bakteri patogen selain bakteri coliform, karena hasil penelitian (Tabel 2) menunjukkan tidak terdapat pengaruh pemberian air rebusan kunyit terhadap jumlah bakteri coliform $(\mathrm{P}>0,05)$. Albazaz dan $\mathrm{Bal}$ (2014) menyatakan bahwa mikroba yang ada didalam usus halus unggas diantaranya yaitu bakteri (predominan), fungi, dan protozoa. Katukurunda et al. (2015) menyatakan bahwa ekstrak kunyit dapat digunakan sebagai antimikrobial yang akan melawan bakteri, fungi, virus, dan kapang. Teow et al. (2016) menyatakan bahwa bakteri yang akan menurun akibat adanya senyawa kurkumin diantaranya yaitu jenis bakteri $S$. aureus, Trichophyton gypseum, Salmonella paratyphi, dan Mycobacterium tuberculosis.

\section{Jumlah Bakteri Coliform pada Usus Halus Ayam Broiler}

Jumlah bakteri coliform pada usus halus ayam broiler akibat pemberian air rebusan kunyit disajikan dalam Tabel 2. Hasil perhitungan analisis ragam menunjukkan bahwa tidak terdapat pengaruh perlakuan pemberian air rebusan kunyit $(\mathrm{P}>0,05)$ terhadap jumlah bakteri coliform pada usus halus ayam broiler. Total bakteri coliform pada kontrol (T0) yaitu $1,70 \times 10^{6} \mathrm{cfu} / \mathrm{g}$ (6,20 log cfu/ml). Khosravivar et al. (2014) menyatakan bahwa jumlah bakteri coliform pada usus ayam broiler periode finisher yaitu $6,04 \log \mathrm{cfu} / \mathrm{g}$. Tidak berpengaruhnya perlakuan terhadap jumlah bakteri coliform diduga akibat senyawa antimikrobial kurkumin pada kunyit tidak efektif menekan jumlah bakteri coliform, namun kurkumin mampu menurunkan jumlah bakteri patogen selain bakteri coliform. Moghadamtousi et al. (2014) dan Selvam et al. (2012) menyatakan bahwa senyawakurkuminyang terdapat pada kunyit mampu menurunkan total bakteri E.coli, P. Aeruginosa, Staph. auerus dan S. Epidermis, Pseudomonas auruginosa, Vibrio harveyi. Enterococcus faecolis, S. lutea, 
Vibrio cholera yang merupakan kelompok bakteri patogen.

Pemberian air rebusan kunyit pada ayam broiler penelitian ini bertujuan untuk menurunkan jumlah bakteri patogen dalam usus halus ayam broiler karena kunyit mengandung senyawa kurkumin yang merupakan senyawa antibakteri. Prinsip kerja dari senyawa antibakteri yaitu menghambat pertumbuhan suatu bakteri atau merusak sel bakteri sehingga bakteri tersebut mati. Penurunan jumlah bakteri patogen diharapkan mampu meningkatkan jumlah bakteri menguntungkan pada usus halus ayam broiler. Sesuai dengan pendapat Natsir et al. (2016) menyatakan bahwa kunyit (Curcuma domestica) dapat digunakan sebagai antibiotik alami karena mengandung senyawa aktif kurkumin yang mampu menekan mikroba patogen.

Hasil penelitian menunjukkan bahwa total coliform pada usus halus ayam broiler tidak berbeda antar perlakuan $(\mathrm{P}>0,05)$. Meskipun begitu, terdapat kecenderungan penambahan air rebusan kunyit mampu menurunkan total bakteri coliform dibandingkan dengan T0 (tanpa perlakuan). Sesuai dengan pendapat Yulika (2009) yang menyatakan bahwa mekanisme kerja senyawa antibakteri yaitu mempengaruhi sintesis dinding sel, mengganggu atau merusak fungsi membran, menghambat sintesis asam nukleat, dan menghambat sistesis protein pada bakteri patogen. Gupta et al. (2015) menyatakan bahwa hasil pemeriksaan mikroskopis menunjukkan bahwa senyawa kurkumin yang ada pada kunyit mampu mendeformasi morfologis sel bakteri patogen, yaitu dengan merusaksitoplasma sehingga mengalami gangguan sel dan bakteri patogen mengalami lisis.

\section{Jumlah Bakteri Asam Laktat (BAL) pada Usus Halus Ayam Broiler}

Jumlah bakteri asam laktatpada usus halus ayam broiler akibat pemberian air rebusan kunyit disajikan dalam Tabel 2. Hasil perhitungan analisis ragam menunjukkan bahwa terdapat pengaruh $(\mathrm{P}<0,05)$ perlakuan terhadap jumlah BAL. Total BAL pada penelitian ini yaitu $1,3 \times 10^{8}(\mathrm{cfu} / \mathrm{g})(\mathrm{T} 0)$. Hasil penelitian menunjukkan bahwa perlakuan pemberian air rebusan kunyit cenderung meningkatkan jumlah BAL pada usus halus ayam broiler (T0 vs T1, T3, dan T4). Hal ini sesuai dengan pendapat Namagirilakshmi et al. (2010) bahwa penambahan kunyit dengan level $1 \%$ pada pakan mampu meningkatkan total bakteri asam laktat paling tinggi pada usus halus ayam broiler dibandingkan perlakuan lainnya (level 0,25\%, 0,50\%, 0,75\%). Al-Mashhadani (2015) menyatakan bahwa penambahan kunyit pada pakan mampu meningkatkan total BAL terlihat dari data T1 (kontrol) yaitu 13,99 $\log \mathrm{cfu} / \mathrm{ml}, \mathrm{T} 2$ $(0,20 \%)$ yaitu $17,09 \log \mathrm{cfu} / \mathrm{ml}, \mathrm{T} 3(0,40 \%)$ yaitu $17,03 \mathrm{log} \mathrm{cfu} / \mathrm{ml}$ dan T4 (0,60\%) yaitu $16,81 \% \log \mathrm{cfu} / \mathrm{ml}$.

Fluktuasi jumlah BAL berhubungan dengan jumlah bakteri coliform yaitu semakin sedikit jumlah bakteri coliform cenderung meningkatkan jumlah BAL semakin meningkat dan begitu juga sebaliknya. Hal ini menunjukkan terjadinya competitive ecxclusion yaitu kompetisi antar bakteri (dalam hal ini BAL dan bakteri coliform) untuk mendapatkan ruang dan nutrisi dalam usus halus. Nevy dan Tafsin (2008) menyatakan bahwa salah satu faktor yang mempengaruhi populasi bakteri dalam usus halus yaitu kemampuan berkompetisi dalam mendapatkan nutrisi dan ruang dalam usus halus. Sesuai dengan pendapat Higgins et al. (2007) menyatakan bahwa penambahan bakteri asam laktat pada seka ayam broiler mampu menurunkan jumlah bakteri patogen Salmonella dalam seka ayam broiler $(3,40$ $\log \mathrm{cfu} / \mathrm{ml}$ menjadi $1,87 \log \mathrm{cfu} / \mathrm{ml})$, hal ini menunjukkan adanya competitive exclusion antara bakteri asam laktat dan Salomonella untuk mendapatkan ruang dalam seka.

\section{KESIMPULAN}

Berdasarkan hasil penelitian ini dapat disimpulkan bahwa pemberian air rebusan 
kunyit mampu meningkatkan total bakteri asam laktat dan memberikan hasil yang terbaik pada perlakuan T1 yaitu 4,20 x $10^{8}$ cfu/g. Perlakuan mampu menurunkan total bakteri dan memberikan hasil terbaik pada perlakuan T4 yaitu $0,40 \times 10^{12} \mathrm{cfu} / \mathrm{g}$, tetapi tidak menaikkan/menurunkan total bakteri coliform di dalam usus halus ayam broiler.

\section{DAFTAR PUSTAKA}

Albazaz, R. I. dan E. B. B. Bal. 2014. Microflora of digestive tract in poultry. KSU Doga Bil. Derg. 17 (1): 39-42.

Almashhadani, H. E. 2015. Effect of different levels of turmeric (Curcuma longa) supplementation on broiler performance, carcass characteristic and bacterial count. Egypt. Poult. Sci. 35 (1): 25-39.

Anggitasari, S., O. Sjofan dan I. H. Djunaid. 2016. Pengaruh beberapa jenis pakan komersil terhadap kinerja produksi kuantitatif ayam pedaging. Buletin Peternakan. 40 (3): 287-196.

Estancia, K., Isroli dan Nurwantoro. 2012. Pengaruh pemberian ekstrak kunyit (Curcuma domestica) terhadap kadar air, protein dan lemak daging ayam broiler. Animal Agriculture Journal. 1 (2): 31-39.

Gupta, A., S. Mahajan dan R. Sharma. 2015. Evaluation of antimicrobial activity of Curcuma longa rhizome extract against Staphylococcus aureus. Biotechnology Reports. $6: 51-55$.

Higgins, J. P., S. E. Higgins, J. L. Vicente, A. D. Wolfenden, G. Tellez dan B. M. Hargis. 2007. Temporal Effects of Lactic Acid Bacteria Probiotic Culture on Salmonella in Neonatal Broilers. Poultry Science 86 : 1662-1666.

Katukurunda, K. G. S. C., M. K. W. Gamage, H. A. A. Y. Buddhika, S. D. Prabhashini dan D. Senaratna. 2015. Comparison of microbial aspects, ammonia emission rates and properties of broiler and layer litters after application of turmeric (Curcuma longa) powder. IJIRT. 2 : 19-24.

Khosravifar, O., Y. Ebrahimnezhad., N. Maherisis., R.S.D. Nobar dan G. Galekandi. 2014. Effect of some medicinal plants as feed additive on total coliform count of ileum in Japanese quails (Coturnix coturnix japonica). Int. J. Biosci. 2(4) : 211-220.

Moghadamtousi, S. Z., A. K. Habsah, H. Pouya, T. Hassan, A. Sazaly dan Z. Keivan. 2014. A Review on antibacterial, antiviral, and antifungal activity of curcumin. Hindawi Publishing Corporation BioMed Research International. 1-12.

Namagirilakshmi, S., P. Selvaraj, K. Nanjappan, S. Jayachandran dan P. Visha. 2010. Turmeric (Curcuma Longa) as an alternative to in-feed antibiotic on the gut health of broiler chickens. Tamilnadu Journal of Veterinary and Animal Sciences. 6 (3): 148-150.

Natsir, M. H., E. Widodo dan Muharlien. 2016. Penggunaan kombinasi tepung kunyit (Curcuma domestica) dan jahe (Zingiber officinale) bentuk enkapsulasi dan tanpa enkapsulasi terhadap karakteristik usus dan mikroflora usus ayam pedaging. Buletin Peternakan. 40 (1): 1-10.

Nevy, D. H. dan M. Tafsin. 2008. Penggunaan mannanoligosakaridas dari bungkil inti kelapa sawit sebagai pengendali Salmonellapada ternak unggas. Fakultas Pertanian, Universitas Sumatera Utara, Medan. (Karya Ilmiah).

Selvam, R., A. J.A. R. Singh dan K. Kalirajan. 2012. Anti-microbial activity of turmeric natural dye against different bacterial strains. J. of Applied Pharmaceutical Science. 2 (6): 210212.

Teow, S., L. Kitson, A. A. Syed, S. K. Alan dan P. Suat-Cheng. 2016. Antibacterial action 
of curcumin against Staphylococcus aureus: A Brief Review. Hindawi Publishing Corporation Journal of Tropical Medicine. 1-10.
Yulika, H. 2009. Pola Resistensi Bakteri yang Diisolasi dari Bangsal Bedah Rumah Sakit. Fakultas Kedokteran, Universitas Indonesia. (Skripsi). 